\title{
ORIENTASI KEWIRAUSAHAAN PETANI BROKOLI SKALA KECIL DALAM MENGHADAPI PERMINTAAN PASAR TEKSTUR (STUDI KASUS DI GAPOKTAN LEMBANG AGRI KECAMATAN LEMBANG KABUPATEN BANDUNG BARAT) Entrepreneuriale Orientation Small Scale Farmers Of Broccoli In The Face Of Structured Marcet Demand
}

\author{
Gema Wibawa Mukti, Rani Andriani Budi Kusumo, Pandi Pardian \\ Universitas Padjadjaran, Sumedang \\ gema.wibawa@unpad.ac.id
}

\begin{abstract}
Broccoli is one of the prospective horticultural products to be developed, beside it has a good nutrition for health, broccoli also hasan interesting physical form. Broccoli is generally preferred by consumers of modern market, sold as fresh with adjust table size with consumer demand. On the other hand, broccoli has aperishable nature, with an unique morphological characteristics. Modern market demand requires a certainspec for broccoli, it cause farmers had tochange the way they do in their business, so that their products are well received by the modern market. There fore, this study aims to determine the entrepreneurial orientation offarmersso it canmeet the demand ofbroccolito themodernmarket. Broccoli's Farmer has a high entrepreneurial spirit, as seen from the orientation of farmers in view the future. Farmers see the modern market as an alternative market with a huge potential market in the future, so that the farmers do a variety of creative effort to make their business performance more efficiently so it can serve the modern market better. The method usedinthisstudyis thecase studies method, theanalysis techniqueused isdescriptive qualitativeanalysis. Research shows that broccoli farmers as an entrepreneur has an unique characteristics and valuesin running their business. Broccoli farmes entrepreneurial orientation in Kecamatan Lembang emphasizes the creation of business innovation, always doing to do the improvement process of their supply chain product, namely with implementing strategies for business collaboration with other actors in the broccoli supply chain. They also always proactivein receivinga request from the modern market as an alternative market for their business, so their businesses can be more competitive and be able to runcontinuously.
\end{abstract}

Keywords: Entrepreneurial orientation, Creative,Structured market, Business Innovation

\begin{abstract}
ABSTRAK
Brokoli merupakan salah satu produk hortikultura yang prospektif untuk dikembangkan, karena disamping memiliki nutrisi yang baik untuk kesehatan, brokoli memiliki bentuk fisik yang mena rik. Brokoli umumnya disukai oleh konsumen pasar modern, dijual dalam bentuk fresh dengan ukuran yang disesuaikan dengan permintaan konsumen. Di sisi lain, brokoli memiliki sifat mudah rusak, dengan sifat morfologis yang unik. Kulitnya yang berongga menyebabkan brokoli mudah mengalami penyusutan. Permintaan pasar modern yang mensyaratkan spek tertentu bagi brokoli, menyebabkan petani harus merubah cara bisnisnya, sehingga produk mereka dapat diterima dengan baik oleh pihak pasar modern. Oleh karena itu penelitian ini bertujuan untuk mengetahui orientasi kewirausahaan petani sehingga dapat memenuhi permintaan brokoli kepada pasar modern. Petani Brokoli memiliki semangat berwirausaha yang tinggi, hal ini terlihat dari orientasi petani dalam melihat masa depan. Petani melihat pasar modern sebagai pasar alternatif pasar yang sangat potensial di masa yang akan datang, sehingga petani melakukan berbagai usaha kreatif agar kinerja bisnis mereka lebih efisien sehingga dapat melayani pasar modern lebih baik. Metode yang digunakan dalam penelitian ini adalah menggunakan studi kasus, dengan teknik analisis yang digunakan adalah analisis deskriptif kualitatif. Hasil Penelitian menunjukkan
\end{abstract}


bahwa petani brokoli sebagai seorang wirausahawan memiliki karakteristik dan nilai yang unik dalam menjalankan bisnis mereka. Orientasi wirausaha petani brokoli di Kecamatan Lembang menekankan kepada penciptaan inovasi usaha, senantiasa melakukan proses perbaikan rantai pasok produk mereka, yaitu dengan menerapkan strategi kolaborasi bisnis dengan pelaku lain yang terdapat dalam rantai pasok brokoli. Mereka juga selalu proaktif dalam menerima permintaan dari pasar modern sebagai pasar alternatif bagi mereka, sehingga usaha mereka semakin berdaya saing dan mampu berjalan secara berkelanjutan.

Kata Kunci: Orientasi Kewirausahaan, Kreatif, Pasar Terstruktur, Inovasi Bisnis

\section{PENDAHULUAN}

Gupta (2004) menyatakan bahwa pertanian adalah bagian yang tidak terpisahkan dalam peradaban umat manusia di muka bumi ini. Manusia secara fitrah memerlukan bahan pangan dan menjadi kebutuhan primer yang harus dipenuhi agar manusia dapat meneruskan kelangsungan hidupnya. Bapak Revolusi Hijau, Norman Ernest Bourlag pada tahun 1953 menemukan teknik budidaya tanaman yang dapat memberikan hasil produksi yang tinggi. Semenjak penemuan ini manusia mulai menerapkan teknologi dalam aktivitas budidaya tanaman untuk menghasilkan tanaman yang memiliki produktivitas tinggi. Hingga tahun 2016, secara umum pertanian di dunia masih menerapkan revolusi hijau sebagai isu utama pengembangan pertanian di suatu negara atau wilayah, meskipun dalam 10 tahun terakhir muncul isu pertanian organik dan juga isu rekayasa genetik.

Kebutuhan pangan dunia saat ini dikuasai oleh perusahaan - perusahaan besar (Multinational Corporation), yang mengandalkan modal/capital yang besar, luas lahan yang besar sehingga mereka dapat menghasilkan produk yang murah karena dapat menekan harga pokok produksi yang rendah (Sumaryanto, 2010). Namun demikian, di negara negara berkembang, peranan pertanian skala kecil masih menjadi sektor yang memegang peranan penting dalam pembangunan suatu negara. Indonesia sebagai salah satu negara berkembang, pertanian skala kecil masih menjadi mata pencaharian andalan dimana sekitar $90 \%$ petani di Indonesia memiliki usaha pertanian skala kecil.

Perubahan sistem perdagangan secara global menarik negara - negara berkembang ke dalam perdagangan global. Implikasi dari perdagangan global ini adalah munculnya standarisasi produk produk pertanian yang mengacu pada permintaan konsumen di negara maju. Kondisi ini tentunya menguntungkan para pelaku pertanian skala besar karena mereka memiliki skala usaha yang besar sehingga produknya lebih berdaya saing, sedangkan bagi petani skala kecil hal ini menjadi beban berat karena mereka harus bersaing dengan pelaku usaha pertanian skala besar. Kondisi ini tentunya menjadi suatu keniscayaan yang harus dihadapi oleh petani petani kecil di Indonesia, karena mau tidak mau mereka harus bersiap menghadapi perubahan iklim usaha yang ada saat ini.

Di balik kondisi persaingan usaha pertanian yang semakin kompetitif, pasar hasil pertanian semakin meningkat setiap tahunnya. Seiring dengan semakin bertambahnya jumlah manusia di muka bumi ini, maka dapat dipastikan kebutuhan pangan pun akan semakin bertambah setiap tahunnya. Salah satu produk pertanian yang tingkat permintaannya tinggi adalah tanaman sayuran. Masyarakat saat ini telah memahami pentingnya sayuran bagi kesehatan, sehingga mereka menuntut produk sayuran yang memiliki kualitas yang baik sehingga dapat memberikan manfaat bagi konsumen (Richer, 2003). Kebutuhan sayuran dalam negeri belum semua dapat dipenuhi oleh petani local, hal ini terlihat dari impor yang dua sampai tiga kali lebih besar dibandingkan dengan ekspor sayuran (Departemen Pertanian, 2008). Fakta ini menunjukkan bahwa pasar produk pertanian di Indonesia memiliki potensi yang sangat besar. Tingkat impor yang tinggi tentunya menjadi suatu peluang yang menguntngkan bilamana produk impor tersebut digantikan oleh produk yang dihasilkan oleh petani lokal. 
Kemudahan informasi memudahkan konsumen memperoleh informasi akan produk yang mereka inginkan. Tidak terkecuali untuk produk pertanian, konsumen yang semakin mengerti tentunya menginginkan produk pertanian yang berkualitas. Tentunya hal ini menjadi tantangan terutama bagi petani skala kecil, karena mereka dituntut untuk berubah dari kebiasaan yang sudah mereka miliki selama ini. Meskipun mereka menjual produk kepada tengkulak atau Bandar, namun mereka saat ini harus mulai memikirkan kualitas produk yang mereka jual agar mereka dapat menjual produknya dengan harga yang lebih baik dari biasanya. Petani semakin dituntut untuk kreatif dan inovatif dalam menjalankan usahanya sehingga mereka dapat memperloleh benefit yang lebih besar dari usaha yang mereka jalankan.

Petani saat ini mau tidak mau harus memiliki orientasi kewirausahaan, sehingga usaha mereka berdaya saing dan produk yang mereka hasilkan dapat diterima oleh konsumen modern saat ini. Kajian utama dalam penelitian ini dititikberatkan pada petani brokoli. Brokoli adalah produk hortikultura yang mudah rusak dan memerlukan penanganan khusus agar panen yang dihasilkan dapat dijual dengan harga yang mahal. Brokoli adalah sayuran bernilai ekonomi tinggi, yang memerlukan penanganan khusus sehingga diperlukan perlakuan khusus yang harus dilakukan oleh petani. Pertanyaan yang muncul adalah apakah petani bersedia untuk memberikan perlakuan - perlakuan tersebut. Tentunya petani yang memiliki orientasi kewirausahaan memiliki pandangan yang berbeda dengan petani pada umumnya, dimana mereka melihat jika ingin mendapatkan keuntungan yang besar, maka diperlukan pengorbanan yang proporsional pula. Berdasarkan laporan World Economic Forum Tahun 2013, memperlihatkan bahwa suatu usaha harus diiringi oleh sebuah inovasi, tidak peduli seberapa besar usaha tersebut telah menggunakan teknologi yang canggih. Petani yang berorientasi kewirausahaan diharapkan mampu bertahan dan memiliki usaha yang memiliki daya saing tinggi. Berdasarkan latar belakang tersebut, maka penelitian ini dititikberatkan untuk melihat orientasi kewirausahaan petani brokoli dengan skala usaha kecil dalam menghadapi pasar terstruktur atau konsumen modern.

\section{Petani Skala Kecil}

Hingga saat ini, acuan petani kecil atau petani skala kecil belum dirumuskan secara tegas dalam suatu ukuran atau standar tertentu. Von Braun (2004) melihat skala usaha dilihat dari luasan lahan yang dimiliki oleh petani, semakin kecil luas lahan yang dimiliki petani bisa dikatakan semakin kecil skala usaha petani tersebut. Namun permasalahan yang muncul adalah adanya perbedaan karakteristik lahan, teknologi dan juga jenis komoditas sehingga dengan luasan yang sama mungkin saja memiliki perbedaan nilai. Sebagai ilustrasi petani brokoli dan petani padi dengan luas lahan 0,5 Hektar tentu memiliki nilai yang berbeda sehingga tidak dapat diperbandingkan diantara keduanya.

Dilihat dari sudut pandang pendapatan, petani skala kecil adalah petani yang memiliki tingkat pendapatan yang rendah. Terdapat beberapa kajian yang melihat bahwa standar atau ukuran pendapatan juga belum mampu menggambarkan skala usaha petani. Secara teoritis, petani kecil otomatis berpendapatan kecil dan sebaliknya. Namun hal ini belum dapat dibuktikan karena di beberapa kasus ada juga petani kecil namun pendapatannya besar (kasus pada petani tanaman hias). Berdasarkan penelitian Hayami (1998), tidak selamanya usahatani skala kecil tidak optimal, bahkan yang terjadi adalah sebaliknya dimana usahatanani skala kecil justru lebih optimal karena penggunaan tenaga kerja keluarga yang lebih murah sehingga biaya produksi lebih efisien. Namun demikian, kegagalan dalam usahatani skala kecil skalanya akan lebih luas karena akan berkaitan dengan perekonomian negara secara makro, karena kegagalan ini akan menyebabkan kemiskinan dan hilangnya lapangan pekerjaan bagi masyarakat di level bawah. 
Berdasarkan hasil sensus pertanian tahun 2013 yang dilakukan oleh Kementerian Pertanian, memperlihatkan bahwa jumlah petani berkurang sebanyak 5,1 juta orang dari tahun 2003 - 2013. Tentunya fenomena ini menunjukkan bahwa sektor pertanian dianggap tidak lagi mampu memberikan harapan pendapatan bagi mereka, sehingga mereka harus mencari sumber pendapatan lainnya di luar pertanian. Namun apabila melihat jumlah penduduk yang terus bertambah setiap tahun, tentunya menunjukkan bahwa sektor pertanian sangat prospektif untuk diusahakan oleh masyarakat petani di Indonesia. Pertanyaannya adalah bagaimana petani mengusahakan usahatani nya agar usahanya tersebut memberikan pendapatan yang layak bagi mereka. Santo Sutoyo dalam buku Bungaran saragih pernah mengemukakan bahwa masih banyak orang yang menganggap bahwa pertanian atau agribisnis adalah sebuah pekerjaan yang sederhana, yang bisa dilakukan oleh semua orang, yang dikerjakan secara konvensional dimana didalamnya terdapat kegiatan produksi di lahan, panen kemudian memasarkan produk yang dihasilkan apa adanya, tanpa memperhatikan keinginan konsumen.

Bungaran Saragih (2015) mengatakan bahwa petani dan para pelaku usaha pertanian yang terdapat dalam suatu rantai tata niaga/rantai pasok harus mampu memperhatikan perubahan pasar sebagai sesuatu yang dinamis dan harus direspon dengan penerapan inovasi dan teknologi dalam usahatani yang mereka jalankan. Petani bukan lagi sebagai produsen penghasil produk pertanian, namun harus berubah menjadi petani yang berorientasi kewirausahaan, yang menghasilkan produk pertanian kualitas premium bagi konsumen modern. Bungaran Saragih mengatakan bahwa perlu adanya perubahan sikap mental produsen konvensional menjadi produsen modern yang berorientasi pada konsumen sebagai tujuan akhir mereka.

\section{Orientasi Kewirausahaan}

Dalam pandangan masyarakat, kewirausahaan identik dengan pengusaha atau orang yang bergerak dalam bidang bisnis. Secara teroritis, Suryana (2003) mengatakan bahwa kewirausahaan adalah suatu kemampuan kreatif dan inovatif yang dimiliki oleh seseorang atau organisasi, dalam mencari sumberdaya yang kemudian digunakan untuk mencari peluang untuk mencapai suatu tujuan. Zimmerer (1996) berpendapat bahwa seorang entrepreneur akan mencapai suatu kesuksesan apabila dia mampu berpikir dan melakukan sesuatu baik itu sesuatu yang baru ataupun lama dengan cara yang baru. Ilmu Kewirausahaan sendiri adalah suatu disiplin ilmu yang mempelajari tentang nilai, kemampuan dan perilaku seseorang dalam menghadapi suatu tantangan dalam kehidupannya untuk memperoleh sesuatu yang bermanfaat bagi kehidupannya dengan berbagai risiko yang mungkin akan dihadapinya dalam proses pencapaian nya. Zimmerer (1996) mengungkapkan bahwa kewirausahaan adalah hasil dari suatu proses sistematis yang disiplin dalam penerapan kreativitas dan inovasi dalam memenuhi kebutuhan dan peluang pasar. Seorang entrepreneur adalah orang yang mampu mengenali potensi mereka sendiri dan senantiasa belajar untuk mengembangkan potensi tersebut sehingga mereka dapat menangkap peluang yang ada serta mengelola sumberdaya yang dimilikinya untuk menangkap peluang tersebut. Petani modern saat ini harus memiliki kemampuan ini, karena pada prinsip nya peluang pasar produk pertanian akan selalu tersedia sangat luas karena manusia pasti akan selalu makan, tidak mungkin manusia tidak makan untuk bertahan hidup.

Petani modern pada masa kini dituntut untuk memiliki orientasi terhadap kewirausahaan apabila mereka ingin bertahan dalam aktivitas usahatani mereka. Covin dan Slevin (1991) menjelaskan bahwa orientasi kewirausahaan mencakup perilaku inovatif dari seorang entrepreneur, keberanian mengambil risiko dan berani bertindak untuk mencapai suatu tujuan.Runyan (2008), menejaskan bahwa sebuah perusahaan atau individu disebut memiliki orientasi kewirausahaan apabila perusahaan tersebut memiliki produk yang inovatif artinya produk yang adaptable terhadap permintaan pasar atau konsumen yang dinamis, kemudian individu tersebut juga memiliki 
keberanian dalam mengambil risiko. Pengambilan risiko ini terkait dengan segala hal yang berkaitan dengan aktivitas bisnisnya risiko ini terkait dengan segala hal yang berkaitan dengan aktivitas bisnisnya.

Perubahan pasar yang dinamis tentunya mengharuskan petani untuk menyesuaikan proses bisnisnya secara adaptif pula. Petani di Indonesia umumnya dan Jawa Barat khususnya adalah petani dengan luas lahan yang kecil (0,2 Ha) dengan tingkat produktivitas yang rendah karena input teknologi yang rendah pula. Tentunya hal ini akan menyulitkan petani untuk mengikuti perubahan pasar apabila petani nya tidak berubah. Fokus utama perubahan yang dimaksud disini adalah perubahan pada individu petani, bukan pada apa yang harus dimiliki petani untuk menunjang usahatani nya, namun apa yang dilakukan petani agar usahataninya dapat bertahan dan berkembang dalam era pasar modern saat ini.

Runyan (2008) menjelaskan bahwa orientasi kewirausahaan merupakan suatu cara/proses bisnis/aktivitas yang dijalankan oleh seorang pelaku usaha untuk memenangkan persaingan atau juga untuk memenuhi permintaan konsumen agar usahanya tersebut tetap berjalan dan juga berkembang. Pelaku usaha juga memiliki tiga ciri utama yaitu inovatif dalam menjalankan usahanya, berani mengambil risiko untuk pengembangan usahanya dan selalu belajar mencari sesuatu yang baru untuk senantiasa memperbaiki bisnisnya.

\section{Inovasi}

Aktivitas inovasi di sektor pertanian dipicu oleh adanya perubahan pengetahuan konsumen atas suatu produk, semakin berkembangnya pasar modern sebagai pasar alternatif bagi petani yang harus digarap dengan serius. Inovasi yang dilakukan petani tidak hanya dilakukan pada produk, namun juga proses bisnis, kelembagaan dan juga inovasi sosial. Definisi inovasi banyak dikemukakan oleh pakar maupun praktisi, diantaranya yang dikemukakan oleh Avanti (2010) bahwa inovasi adalah suatu keberhasilan dalam aktivitas ekonomi dikarenakan Pasar Terstruktur adanya suatu proses atau aktvitas pengelan cara baru atau kombinasi baru dari cara - cara lama dalam mentransformasi input menjadi output (produk, teknologi, new way ) sehingga dapat menghasilkan suatu perubahan yang signifikan dalam perbandingan antara nilai guna suatu produk yang dirasakan oleh konsumen dan harga yang ditetapkan oleh produsen. Intinya inovasi yang berhasil adalah inovasi yang dapat menciptakan nilai lebih besar bagi konsumen sebagai pengguna dari produk kita.

Orientasi Kewirausahaan petani skala kecil memperlihatkan usaha atau upaya dari petani untuk senantiasa berubah dan proaktif dalam menghadapi perubahan pasar, berani mengambil risiko dalam aktivitas usahanya dan mampu beradaptasi dengan perubahan inovasi yang ada di dunia usaha pertanian saat ini (Matsuno, et al, 2002). Permintaan pasar produk hortikultura yang senantiasa berubah, menjadi suatu keniscayaan yang harus dihadapi petani di Indonesia umumnya dan Jawa Barat khususnya. Menjadi Petani yang proaktif, senantiasa beradaptasi dengan pasar dan berani menampilkan sesuatu yang berbeda tentu menjadi suatu keharusan apabila petani ingin bertahan dalam usahatani nya, atau lebih jauh lagi jika petani ingin semakin berkembang dalam usahatani nya (Slater and Narver, 1994).

Inovasi yang dilakukan petani skala kecil tentu berbeda dengan inovasi yang dilakukan oleh pengusaha skala besar. Penelitian ini lebih menitikberatkan pada kajian proses bisnis yang dilakukan oleh petani sehingga dia dapat bertahan dan dapat mengembangkan usahanya sehingga produk yang dihasilkan petani dapat diterima oleh pasar, terutama pasar modern. Inovasi yang dilakukan pada sektor pertanian tentunya tidak dapat dilakukan sendiri, namun terintegrasi dengan pelaku lainnya dalam suatu rantai tata niaga suatu produk pertanian. Kolaborasi dengan pedagang kecil, pedagang besar tentunya menjadi suatu keniscayaan yang tidak dapat dihindarkan dan harus dilakukan oleh petani jika usahanya ingin terus berkembang. 
Tomy Perdana (2012) mengatakan bahwa pasar terstruktur merupakan alternatif pasar yang dapat dipilih produsen sayuran skala kecil untuk menghindari risiko fluktuasi harga. Karakteristik pasar terstruktur adalah adanya kesepakatan antara produsen dan pembeli secara formal ataupun informal berupa komitmen untuk memasok sayuran secara konsisten, baik kuantitas maupun kualitas dengan harga bersaing. Pasar terstruktur menuntut produsen kecil untuk memiliki daya saing agar mampu bersaing dengan pemasok lainnya yang memiliki skala ekonomi lebih besar. Pasar terstruktur terdiri atas supermarket, ekspor, industri dan jasa pangan.

\section{METODE PENELITIAN}

Objek dari penelitian ini adalah orientasi kewirausahaan petani brokoli yang menjual produknya ke pasar terstruktur. Tempat Penelitian ditentukan secara sengaja dengan pertimbangan bahwa petani Brokoli di Kecamatan Lembang saat ini telah menembus pasar terstruktur dengan dalam aktivitas bisnis mereka.

Metode penelitian yang digunakan dalam penelitian ini adalah desain kualitatif eksploratori. Teknik penelitian yang digunakan dalam penelitian ini adalah teknik studi kasus, yaitu penelitian dengan pendekatan yang bertujuan mempertahankan keutuhan (wholeness) objek penelitian. Penelitian studi kasus bersifat mendalam dan mendetail, (Sugiyono, 2012). Dalam penelitian ini pendekatan secara mendalam akan dilakukan terhadap orientasi kewirausahaan petani yang bertransformasi menjadi petani yang berorientasi pasar terstruktur. Sumber data yang digunakan dalam penelitian ini berupa data primer dan data sekunder.

Rancangan Analisis Data menggunakan metode deskriptif, yaitu untuk menjelaskan orientasi kewirausahaan petani Brokoli di Kecamatan Lembang Kabupaten Bandung Barat. Variabel yang akan dianalisis dalam kajian ini adalah (1) aktivitas petani brokoli dalam menjalankan usaha mereka dan melihat perilaku inovatif mereka dalam aktivitas mereka tersebut ; (2) Keputusan yang diambil dalam aktivitas bisnis mereka untuk mendapatkan keuntungan dalam bisnis mereka (perilaku proaktif).

\section{HASIL DAN PEMBAHASAN}

\section{Petani Brokoli Di Lembang}

Petani Brokoli di Lembang terdiri dari dua jenis, yaitu petani yang menanam sendiri brokoli nya dan petani yang tergabung dalam suatu kelompok tani. Hasil di lapangan menunjukkan bahwa saat ini petani sebagian besar tergabung dalam suatu Kelompok Tani atau Gabungan Kelompok Tani. Petani Brikoli di Kecamatan Lembang tergabung dalam Gapoktan Lembang Agri yang menaungi 9 kelompok tani.

Tergabungnya petani dalam kelompok tani dan Gapoktan Lembang Agri didasari oleh permasalahan yang seringkali petani rasakan dalam menjalankan usahatani mereka. Selama ini petani masih menjalankan usahanya secara konvensional, berdasarkan apa yang mereka pelajari dari orang tua atau lingkungannya selama ini. Petani menjual produknya kepada pihak pasar tradisional, sehingga mereka tidak terlalu memperdulikan proses on farm, karena mereka beranggapan bahwa produk yang mereka hasilkan "dihargai" sama saja oleh pihak pasar tradisional.

Permasalahan petani dalam menjual hasil panennya adalah tidak ada kepastian harga jual yang proporsional atau layak karena kuantitas yang sedikit dan juga kualitas yang kurang baik. Pasar tujuan petani juga saat ini yaitu pasar tradisional tidak mensyaratkan kuantitas dan kualitas yang baik, sehingga tidak ada insentif bagi petani untuk menghasilkan produk yang berkualitas. Kehadiran pasar modern dan terstruktur tentunya menjadi alternatif pasar bagi petani, sehingga mereka dapat menjual produknya dengan harga yang lebih baik. Namun hal ini diikuti oleh konsekuensi lain ,yaitu tuntutan akan kualitas produk yang sesuai dengan permintaan pasar dan juga kuantitas yang juga harus disesuaikan dengan kebutuhan pasar. Produk yang sesuai dengan spek pasar dan juga jumlah yang ditetapkan oleh pasar tentunya menjadi tantangan baru bagi petani, khususnya petani skala kecil. 
Permasalahan petani dalam menjual hasil panennya adalah tidak ada kepastian harga jual yang proporsional atau layak karena kuantitas yang sedikit dan juga kualitas yang kurang baik. Pasar tujuan petani juga saat ini yaitu pasar tradisional tidak mensyaratkan kuantitas dan kualitas yang baik, sehingga tidak ada insentif bagi petani untuk menghasilkan produk yang berkualitas. Kehadiran pasar modern dan terstruktur tentunya menjadi alternatif pasar bagi petani, sehingga mereka dapat menjual produknya dengan harga yang lebih baik. Namun hal ini diikuti oleh konsekuensi lain ,yaitu tuntutan akan kualitas produk yang sesuai dengan permintaan pasar dan juga kuantitas yang juga harus disesuaikan dengan kebutuhan pasar. Produk yang sesuai dengan spek pasar dan juga jumlah yang ditetapkan oleh pasar tentunya menjadi tantangan baru bagi petani, khususnya petani skala kecil.

Pasar terstruktur di Indonesia saat ini masih didominasi oleh pasar modern yang merupakan korporasi besar dengan jumlah konsumen yang besar pula. Tingkat permintaan pasar terstruktur yang besar tentunya tidak mungkin untuk dipenuhi oleh petani secara individu, karena skala usaha yang kecil tentunya tidak dapat memenuhi semua permintaan tersebut.

Aktivitas pertanian yang monoton karena hanya menjual produk pertanian kepada pasar tradisional dan juga munculnya permintaan pasar terstruktur yang belum dapat terpenuhi karena masih terbatasnya kemampuan petani yang ada di Kecamatan Lembang, khususnya di Desa Cikidang, mendorong para petani membentuk Gabungan Kelompok tani Lembang Agri. Sebelumnya petani hortikultura di Kecamatan Lembang telah memiliki kelompok tani seperti kelompok tani Tauhiid, Berkah
Tani, dan Golek dekol. Namun karena kelembagaan kelompok tani yang belum mampu menjawab kebutuhan petani, maka mereka bersepakat untuk mendirikan Gapoktan Lembang Agri.

Saat ini Gapoktan Lembang Agri terdiri dari Sembilan kelompok tani yakni, Kelompok Tani Tauhid, Saluyu, Alam Tani, Berkah Tani, Mulya Tani, Tani Sangkuriang, Tani Sundung, Tani Putra Lembang, dan Wanita Tani Asih. Hingga saat ini luas lahan yang terdiri dari gabungan kelompok tani seluas 90,2 ha dengan jumlah anggota sebanyak 195 orang.

\section{Orientasi Kewirausahaan Petani Brokoli Dalam Aktivitas Usahatani}

Gapoktan Lembang Agri menjalin kerjasama dengan pasar terstruktur, yaitu supplier - supplier lokal dari pasar - pasar terstruktur. Gapoktan Lembang Agri sebagai wadah petani brokoli skala kecil dalam memasarkan brokoli juga menyediakan penangkar benih brokoli yang diperuntukkan bagi petani anggota Gapoktan juga petani di daerah lain. Hal ini untuk menjaga produksi brokoli petani dengan menyediakan benih berkualitas yang mudah diakses oleh petani.

Dalam menjalankan usahanya, pihak Gapoktan Lembang Agri menyadari bahwa mereka tidak dapat berjalan sendiri, namun memerlukan bantuan atau kerjasama dengan pihak lain yang berkontribusi dalam kegiatan usahatani mereka. Munculnya pasar terstruktur merubah pola permintaan dan secara otomatis merubah aktivitas bisnis petani. Petani yang pada awalnya bekerja sendiri - sendiri, mulai melakukan kerjasama dan kolaborasi dengan pihak lain dalam memenuhi kebutuhan pasar atau konsumen. 


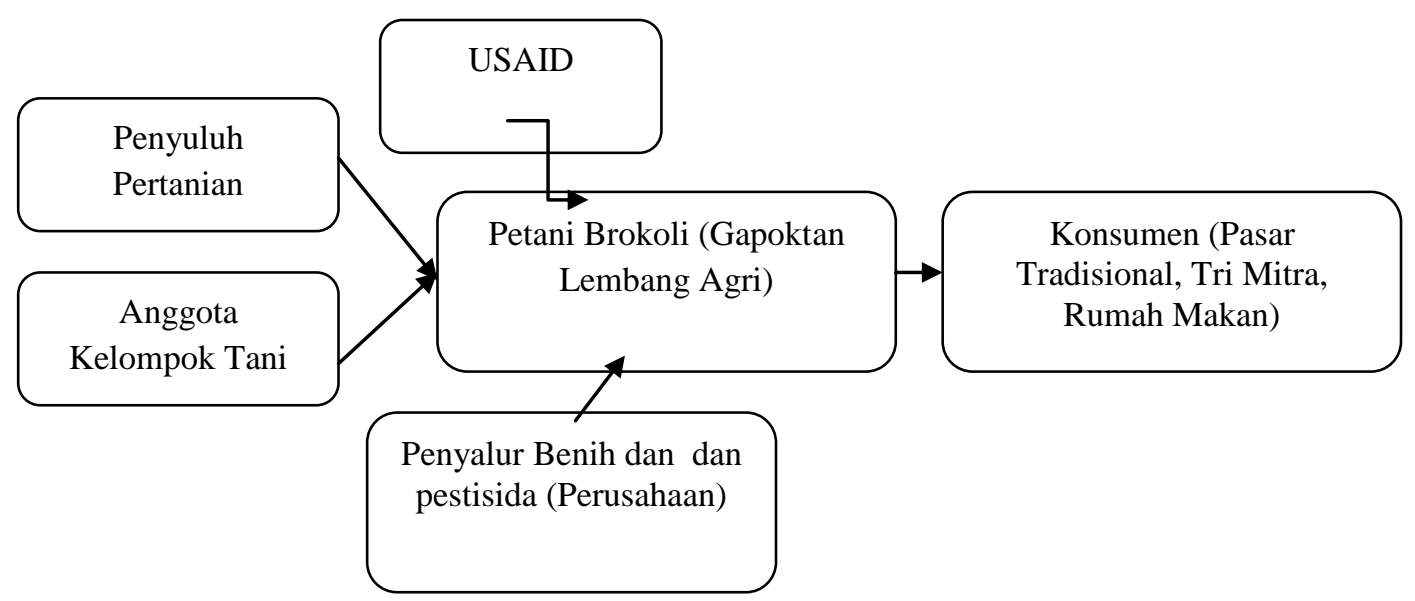

Gambar 1. Mitra Gapoktan Lembang Agri Dalam Memenuhi Pasar Terstruktur

Tabel 1. Spesifikasi Brokoli Untuk Pasar Gapoktan Lembang Agri

\begin{tabular}{cllll}
\hline No. & Karakteristik & \multicolumn{1}{c}{ Supplier Lokal } & \multicolumn{1}{c}{ Pasar Tradisional } & \multicolumn{1}{c}{ Jasa Pangan } \\
\hline 1. & Ukuran Buah/ Bobot & Besar, 300 gr & Besar, 300-400 gr & Besar, 300 gr \\
2. & Tekstur Buah & Keras & Keras & Keras \\
3. & Bentuk Buah & Bunga dan Batang & Bunga dan Batang & Bunga dengan batang \\
& & Bercabang (20 cm) & Bercabang (20 cm) & (7cm) \\
4. & Buah Masak Petik & Matang (Hijau) & Matang (Hijau) & Matang (Hijau) \\
5. & Permukaan & Tidak cacat dan & Tidak cacat dan & Tidak cacat dan tidak \\
& & terinfeksi hama penyakit & terinfeksi hama (ulat) & terinfeksi hama \\
& & (ulat) & & penyakit \\
\hline
\end{tabular}

\section{Sumber : Data Primer Diolah}

Gapoktan Lembang Agri senantiasa berkolaborasi dengan penyedia saprodi, pihak pemerintah, USAID karena mereka membutuhkan mitra sebagai pendukung usaha mereka sehingga mereka mampu memenuhi permintaan pasar terstruktur. Permintaan Brokoli dari pihak pasar yaitu sebanyak 1,5 Ton dengan frekuensi pengiriman sebanyak 3 kali per minggu (@500 Kg). Permintaan pasar terstruktur tentunya memiliki perbedaan dengan pasar tradisional/tidak terstruktur.

Waktu panen sangat menentukan kualitas Brokoli yang dihasilkan. Bentuk sikap proaktif petani brokoli dalam menghadapi perubahan pasar adalah petani aktif untuk menjalin kesepakatan dengan pihak konsumen dalam menentukan volume permintaan dan waktu pengiriman. Adanya kesepakatan yang jelas mengenai volume dan waktu pengiriman tentunya akan memudahkan petani dalam menyusun waktu tanam dan waktu panen yang tepat, sehingga kualitas dan kontinuitas pengiriman dapat dijaga. Hal ini juga menandakan bahwa petani skala kecil telah melakukan perencanaan usahatani yang matang agar mereka dapat memenuhi permintaan pasar secara tepat waktu, tepat ukuran (kualitas) dan tepat jumlah (volume).

Dalam proses bisnis pertanian, kebutuhan akan akses informasi menjadi suatu hal yang sangat penting. Informasi mengenai kebutuhan benih brokoli bersertifikat, pengaturan pola tanam, teknik budidaya brokoli yang baik tentunya menjadi kebutuhan utama petani. Petani menjadi awareakan informasi tersebut karena tuntutan pasar yang senantiasa berubah. Secara otomatis petani menjadi adaptif terhadap adanya perubahan pasar dan teknologi yang ada untuk memenuhi kebutuhan pasar tersebut. Untuk memenuhi kebutuhan akan informasi, petani brokoli dalam Gapoktan Lembang Agri melakukan kolaborasi dengan Dinas Pertanian Provinsi Jawa Barat 


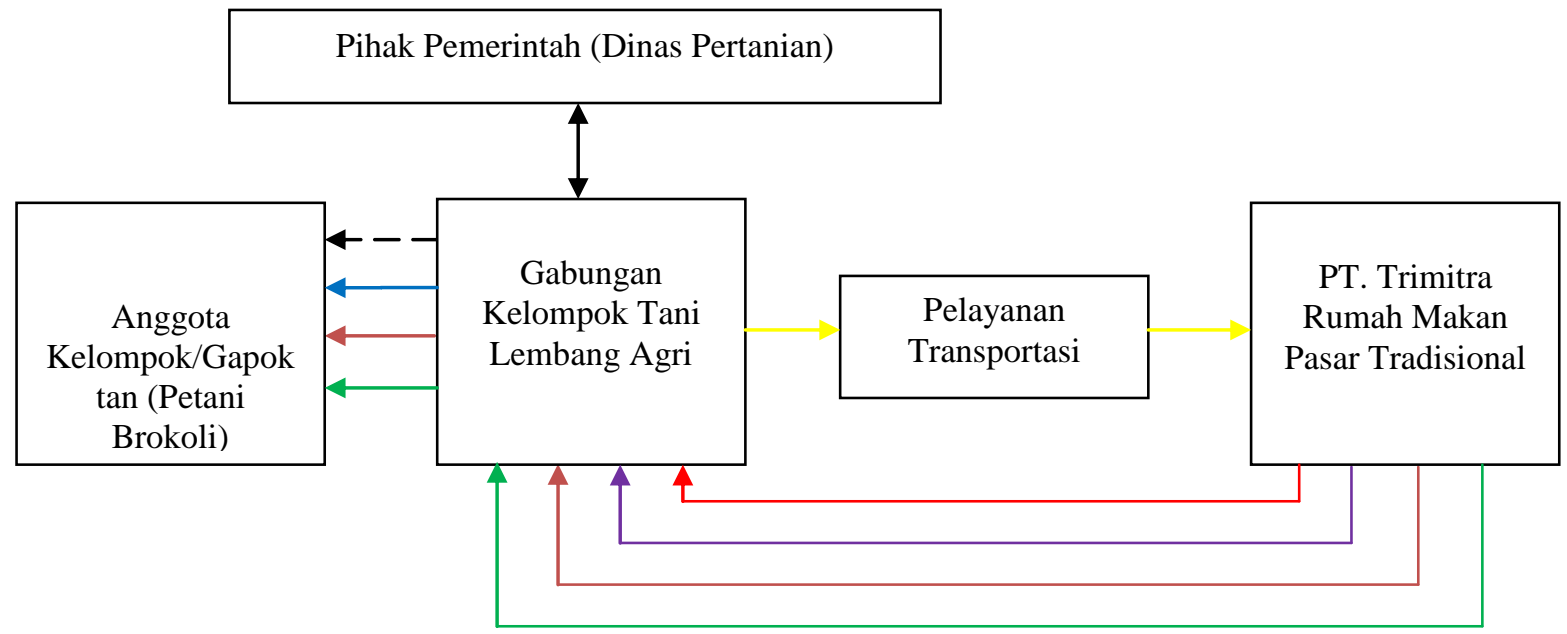

\section{Gambar 2. Model Bisnis Petani Brokoli Untuk Memenuhi Permintaan Pasar Terstruktur}

Keterangan :

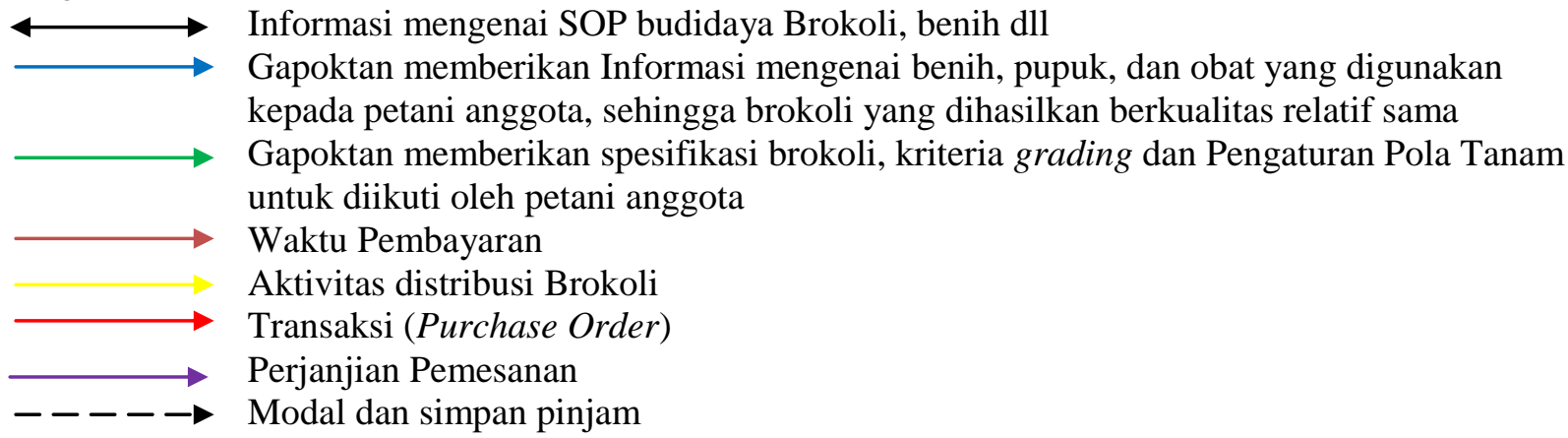

Kolaborasi antara Petani Brokoli (Gapoktan Lembang Agri) dengan pihak Dinas Pertanian merupakan bentuk proaktif dan adaptif petani dalam menghadapi pasar. Kolaborasi ini tentunya harus dilaksanakan berdasarkan kebutuhan petani, tidak hanya mengikuti program dari Dinas Pertanian saja (Buttom Up).

Brokoli adalah tanaman sayuran yang mudah rusak dan mudah mengalami penyusutan. Kadar air yang tinggi menyebabkan brokoli mudah mengalami penyusutan. Untuk mengatasi kendala tersebut, diperlukan penerapan teknologi dan investasi sehingga brokoli dapat terjaga kadar air nya sehingga nilai jualnya tidak turun. Salah satu bentuk upaya Petani Brokoli dalam mensiasati hal ini adalah dengan mempersingkat proses penyimpanan hingga pendistribusian. Hal ini dapat dilakukan tentunya jika telah terjalin kerjasama bisnis yang baik antara petani dan pembeli. Petani yang biasanya menjual produknya secara tradisional, saat ini telah mengalami perubahan dimana mereka dituntut untuk membuat perjanjian yang jelas dengan pihak pembeli.

Perjanjian tertulis merupakan salah satu bentuk aktivitas usaha petani yang berorientasi kewirausahaan, dimana mereka berani untuk mengambil risiko dalam usahataninya. Produk pertanian adalah produk yang memiliki karakteristik mudah rusak, sehingga penjualan produk pertanian dengan sistem kontrak tentunya memiliki risiko yang lebih besar daripada produk non pertanian. Namun dengan perencanaan usaha yang baik dan penerapan pola tanam yang sesuai dengan permintaan pasar tentunya memberikan kepercayaan diri kepada petani dalam Gapoktan untuk menjalin kerjasama tertulis dengan pihak pembeli. 
Peneliti melihat hal ini sebagai bentuk keberanian petani mengambil risiko dalam menentukan pasar mereka. Petani melihat bahwa pasar terstruktur dan pasar modern adalah pasar alternatif bagi mereka, sehingga mereka harus eksis dalam pasar tersebut. Peluang ini rata - rata ditangkap oleh petani - petani yang berusia 40 tahun ke bawah (Data Primer), dimana mereka lebih berani untuk mencoba sesuatu yang baru, cara bertanam yang baru, pasar yang baru, teknologi yang baru, namun tentu dengan perhitungan yang matang. Hal ini tentunya menjadi suatu hal yang sangat positif bagi perkembangan pertanian petani brokoli skala kecil terutama di Kecamatan Lembang.Petani skala kecil umumnya identik dengan golongan masyarakat yang kurang pendidikan, subsisten, terpinggirkan (Ellis, 1988). Petani skala kecil dianggap masih berorientasi pada produkis, tidak berorientasi pasar, sehingga mereka kurang memperhatikan kualitas produknya. Namun demikian, petani khususnya petani brokoli telah beradaptasi dengan perubahan pasar (Orientasi Kewirausahaan). Petani Brokoli yang tergabung dalam Gapoktan Lembang Agri telah melihat konsumen sebagai partner utama mereka dalam aktivitas bisnis nya. Gapoktan Lembang Agri melihat pelanggan dari sisi internal dan dari sisi eksternal. Pelanggan internal adalah petani anggota yang merupakan asset utama dari Gapoktan Lembang Agri, sedangkan pelanggan eksternal adalah PT Trimitra, Jasa Pangan dan Rumah Makan (Gambar 2)

Masing - masing pelaku dalam bisnis brokoli ini, yaitu petani, Gapoktan dan pembeli memiliki komitmen bersama dalam menjalankan bisnis brokoli ini. Masing - masing berkomiten untuk bertanggung jawab dalam menjalankan tugasnya masing masing. Petani anggota bertugas menghasilkan produksi brokoli yang sesuai dengan kebutuhan pasar, Gapoktan memfasilitasi anggotanya dalam memasarkan brokoli dan pelanggan/pembeli menerima Brokoli dan melakukan pembayaran sesuai dengan kesepakatan sebelumnya.

Tabel 2. Service Level Agreement Gabungan Kelompok Tani Lembang Agri dengan Pelanggan Internal dan Eksternal

\begin{tabular}{|c|c|c|}
\hline \multicolumn{2}{|c|}{ Jenis Pelanggan } & \multirow[b]{2}{*}{ Service Level Agreement (SLA) } \\
\hline $\begin{array}{l}\text { Pelanggan } \\
\text { Internal }\end{array}$ & $\begin{array}{l}\text { Pelanggan } \\
\text { Eksternal }\end{array}$ & \\
\hline \multirow[t]{2}{*}{ Petani Anggota } & & $\begin{array}{l}\text { - Pasokan Brokoli dari petani anggota mencapai } 10 \text { ton/bulan. } \\
\text { - Sortir dilakukan di lahan petani dengan standar spesifikasi produk } \\
\text { yang telah disepakati bersama. Kemudian Brokoli tersebut dikemas } \\
\text { dalam plastik bening sesuai dengan permintaan Buyer. } \\
\text { - Pihak Gapoktan mengambil brokoli dari lahan petani dengan waktu } \\
\text { yang sesuai dengan kesepakatan } \\
\text { - Barang reject di Gapoktan maksimal } 5 \% \text { dari total yang diangkut. } \\
\text { - Pembayaran dari gapoktan kepada petani anggota dilakukan setiap } \\
\text { seminggu sekali. }\end{array}$ \\
\hline & $\begin{array}{c}\text { Supplier Lokal (PT } \\
\text { Trimitra) }\end{array}$ & $\begin{array}{l}\text { - PT Trimitra menerima Brokoli dari Gapoktan, tidak lsg dari petani. } \\
\text { - Biaya pengiriman menjadi tanggung jawab Gapoktan } \\
\text { - Waktu pengiriman dilakukan secara konsisten (Tepat waktu, tepat } \\
\text { jumlah, tepat ukuran) } \\
\text { - Pembayaran dilakukan satu hari setelah pengiriman }\end{array}$ \\
\hline
\end{tabular}

Sumber : Data Primer 
Salah satu inovasi Gapoktan Lembang Agri dan Petani anggota dalam melayani konsumen adalah memberikan pelayanan on time delivery. Pelayanan seperti ini untuk produk pertanian tentu memberikan konsekuensi pada pengaturan pola tanam dan aktivitas budidaya di tingkat petani. Petani yang memiliki orientasi kewirausahaan tentunya akan memberikan pelayanan yang optimal kepada pembeli karena mereka memahami bahwa konsumen adalah aspek yang sangat penting dalam kegiatan usaha. Pengaturan waktu tanam yang disiplin, waktu panen dan waktu pengiriman yang disiplin adalah ciri dari petani yang telah memiliki orientasi kewirausahaan. Petani telah beradaptasi dengan pasar, berani mengambil risiko dalam melakukan pemasaran produknya dan senantiasa memberikan pelayanan lebih terhadap pelanggannya (berani tampil beda).

Proses bisnis yang dilakukan merupakan suatu inovasi bisnis yang dapat membuat Gapoktan Lembang Agri menjadi berbeda dengan pesaingnya. Dalam proses Manajemen Usahatani, proses evaluasi harus dilakukan agar ke depan proses bisnis yang dilakukan dapat menjadi lebih baik lagi dengan memberikan profit yang lebih optimal. Petani skala kecil pada umumnya belum melakukan proses evaluasi ini, mereka melakukan kegiatan usahatani berulang - ulang tanpa diikuti dengan pembaharuan di dalamnya. Petani Brokoli di Kecamatan Lembang, mulai melakukan evaluasi terhadap usahataninya. Evaluasi ini dilakukan agar proses bisnis yang berjalan dapat lebih baik dan efisien, sehingga usaha yang dijalankan lebih profitable. Beberapa evaluasi yang dilakukan diantaranya adalah :

1. Pengadaan Benih

Gapoktan Lembang Agri membuat penangkaran benih brokoli sendiri, sehingga mereka dapat membuat sendiri benih yang sesuai dengan permintaan pasar. Penangkar benih ini senantiasa dievaluasi agar benih yang dihasilkan sesuai dengan kebutuhan pasar dan dapat memenuhi kebutuhan petani akan benih brokoli.

2. Tingkat Reject

Untuk mengoptimalkan profit, tentunya gapoktan dan petani anggota harus senantiasa menjaga kualitas brokoli agar tingkat reject dapat semakin diminimalisir. Pemahaman spesifikasi produk di tingkat Gapoktan dan petani harus sama dan masing - masing pihak berkomitmen untuk menjaga spesifikasi produk yang diminta oleh pasar.

\section{KESIMPULAN}

Petani brokoli sebagai seorang wirausahawan memiliki karakteristik dan nilai yang unik dalam menjalankan bisnis mereka. Orientasi wirausaha petani brokoli di Kecamatan Lembang menekankan kepada penciptaan inovasi usaha, senantiasa melakukan proses perbaikan rantai pasok produk mereka, yaitu dengan menerapkan strategi kolaborasi bisnis dengan pelaku lain yang terdapat dalam rantai pasok brokoli. Mereka juga selalu proaktif dalam menerima permintaan dari pasar modern sebagai pasar alternatif bagi mereka, sehingga usaha mereka semakin berdaya saing dan mampu berjalan secara berkelanjutan. Pasar atau konsumen modern atau terstruktur adalah entitas yang sangat dinamis dan selalu berubah. Arus informasi yang semakin cepat menyebabkan konsumen saat ini menjadi semakin pintar, semakin memahami kebutuhan mereka. Perubahan ini tentunya menjadi tantangan yang besar bagi petani skala kecil. Petani skala kecil dengan segala keterbatasannya harus mampu menjawab tantangan ini, karena dalam bisnis, perubahan adalah suatu kepastian yang tidak dapat dihindari oleh semua pelaku usaha. Untuk menghadapi perubahan ini, yang harus dilakukan oleh para pelaku usaha adalah senantiasa beradaptasi/berubah mengikuti perubahan pasar. 


\section{DAFTAR PUSTAKA}

Bungaran Saragih, 2015. Membumikan Paradigma Agribisnis 70 Tahun Profesor Bungaran Saragih. Gaun Persada Press

Brunaker, S., dan Kurvinen, J. (2006). Intrapreneurship, local initiatives in organizational change processes. Leadership \& Organization Development Journal, Vol. 27 (2), 118-132.

Ellis, F. 1988. Peasant Economics, Farm Households and Agrarian Development. Cambridge University Press.

Fontana, A. 2010. Innovate We can, How to Create Value Through Innovation in Your Organization and Society. Manajemen Inovasi dan Penciptaan Nilai. Penebar Swadaya. Jakarta.

Gupta, A.K. 2004. Origin Of Agriculture and Domestication of Plants and Animals Linked To Early Holocene Climate Amelioration. Current Science, Vol 87, No 1, July 2004.

Hayami, Y. 1998. The Peasant in Economic Modernization. In Eicher, C.K and J.M Staatz. International Agricultural Development. Baltimore and London : John Hopkins University Press

Matsuno, K, Mentzer, J.T. and Ozsomer, A (2002). The Effect of Entrepreneurial Proclivity and Market Orientation On Business Performance. Journal of Marketing 66 (3), 18-32.

Morris, M.H., Kuratko, D.F., and Covin, J.G. (2008). Corporate entrepreneurship \& innovation $\left(2^{\text {nd }}\right.$ ed). Mason, $\mathrm{OH}$ : Thomson South-Western.

Perdana, Tomy dkk. 2012. Manajemen Rantai Pasok Hortikultura Untuk Memenuhi Pasar Terstruktur. Bandung.

Richer's. 2003. Produce for Healthy Living Guide. Try - Food International, Inc. Florida.
Runyan, R., Huddleston, P., and Swinney, J., 2006, Entrepreneurial Orientation and Social Capital as Small Firm

Slater, Stanley F. and John C. Narver (1994a), Does Competitive Environment Moderate the Market Orientation-Performance Relationship? Journal of Marketing, 58 (January), 46-55and (1994b), Market Orientation, Customer Value, and Superior Performance, Business Horizons, 37 (2), 2228

Strategies: a Study of Gender Differences from a Resource-Based Mew, Entrepreneurship Management, Vol. 2, pp.455-477.

Sumaryanto, (2010). Eksistensi Pertanian Skala Kecil Dalam Era Persaingan Global. Pusat Sosial Ekonomi dan Kebijakan Pertanian, Badan Penelitian dan Pengembangan Pertanian Kementerian Pertanian.

Suryana, 2003. Kewirausahaan Pedoman Praktis, Kiat dan Proses Menuju Sukses. Penerbit Salemba Empat, Jakarta.

Venkatapathy, R.. (1992). Entrepreneurial attitude orientation among first and second generation entrepreneurs.Paper presented to the nation workshop on Management Research Development held under the avshpiees of the association of Indian management school, Indira Gandhi Institute for development research.

Von Braun, J. 2004. Small Scale Farmers in Liberalised Trade Environment. In Huvio, T., J. Kola, and T. Lundstrom (Eds). Small Scale Farmers in Liberalised Trade Environment. Proceeding of the Seminar on October 2004 in Haiko Finland. Publication No 38 Agricultural Policy, Department of Economics and Management, University of Helsinki. Zimmere. W Thomas, Norman M. Scarborough. 1996. Entrepreneurship and New Venture ormation, New Jersey : Prentice Hall International Inc. Hal 51 